\title{
Human Adipose Tissue-Derived Mesenchymal Stem Cells Abrogate Plasmablast Formation and Induce Regulatory B Cells Independently of T Helper Cells
}

\author{
M. Franquesa, ${ }^{a}$ F. K. Mensah, ${ }^{a}$ R. Huizinga, ${ }^{b}$ T. Strini, $^{a}$ L. Boon, ${ }^{c}$ E. Lombardo, ${ }^{d}$ \\ O. DelaRosa, ${ }^{\text {d J. D. Laman, }}{ }^{\text {b,e }}$ J. M. Grinyó, ${ }^{f}$ W. Weimar, ${ }^{a}$ M. G. H. Betjes, ${ }^{a}$ C. C. BaAn, ${ }^{a}$ \\ M. J. HoOgDUIJN ${ }^{a}$
}

Key Words. B cell • Immunomodulation - Mesenchymal stem cell • Plasmablast • Regulatory B cell (Breg)

${ }^{\mathrm{a}}$ Nephrology and

Transplantation, Department of Internal Medicine and

${ }^{\mathrm{b}}$ Department of Immunology,

Erasmus MC, University

Medical Center, Rotterdam,

The Netherlands; 'Bioceros,

Utrecht, The Netherlands;

${ }^{d}$ TiGenix SAU, Madrid, Spain;

e Department of

Neuroscience/Medical

Physiology, University

Medical Center Groningen,

Groningen, The Netherlands;

${ }^{f}$ Experimental Nephrology

and Transplantation, Hospital

Universitari de Bellvitge-

IDIBELL, Barcelona, Spain

Correspondence: M. Franquesa, Ph.D., Nephrology and Transplantation, Internal Medicine, P.O. Box 2040, internal postal address Na-519, 3000 CA Rotterdam, The Netherlands. Telephone: 31107035418; Fax: • • •; e-mail: m.franquesa@erasmusmc.nl

Received April 3, 2014; accepted for publication October 11, 2014; first published online in Stem Cells EXPRESS November 6, 2014.

(c) AlphaMed Press 1066-5099/2014/\$30.00/0

http://dx.doi.org/

10.1002/stem.1881

\section{ABSTRACT}

Mesenchymal or stromal stem cells (MSC) interact with cells of the immune system in multiple ways. Modulation of the immune system by MSC is believed to be a therapeutic option for autoimmune disease and transplant rejection. In recent years, B cells have moved into the focus of the attention as targets for the treatment of immune disorders. Current B-cell targeting treatment is based on the indiscriminate depletion of B cells. The aim of this study was to examine whether human adipose tissue-derived MSC (ASC) interact with B cells to affect their proliferation, differentiation, and immune function. ASC supported the survival of quiescent B cells predominantly via contact-dependent mechanisms. Coculture of B cells with activated T helper cells led to proliferation and differentiation of $B$ cells into $C D 19^{+} \operatorname{CD} 27^{\text {high }} C D 38^{\text {high }}$ antibody-producing plasmablasts. ASC inhibited the proliferation of B cells and this effect was dependent on the presence of T cells. In contrast, ASC directly targeted B-cell differentiation, independently of T cells. In the presence of ASC, plasmablast formation was reduced and IL-10producing $\mathrm{CD} 19^{+} \mathrm{CD} 24^{\text {high }} \mathrm{CD} 38^{\text {high }} \mathrm{B}$ cells, known as regulatory $\mathrm{B}$ cells, were induced. These results demonstrate that ASC affect B cell biology in vitro, suggesting that they can be a tool for the modulation of the B-cell response in immune disease. STEM CELLS 2015;33:880-891

\section{INTRODUCTION}

B cells are targets for the treatment of multiple autoimmune disorders [1] and the induction of graft survival $[2,3]$ as they are key players in the adaptive immune response. B cells are potent antigen presenting cells (APCs), can produce both pro- and anti-inflammatory cytokines, and have the capacity to differentiate into immunoglobulin-producing plasma cells [4, 5]. The surface immunoglobulin on $B$ cells serves as the B-cell receptor (BCR) for antigen, and upon activation the $B$ cell interacts with its cognate $\mathrm{CD}^{+}$helper $\mathrm{T}$ cell via interaction between the major histocompatibility complex class II and the T-cell receptor. In addition, pivotal costimulation is provided through binding of CD40 to CD40 ligand on the T cell. This results in enhanced $\mathrm{B}$-cell proliferation and differentiation into immunoglobulin-secreting plasmablasts and plasma cells and the formation of memory B cells. Elevated levels of these B-cell subsets in the circulation are associated with poor graft outcome [6-8] and increased severity of autoimmune diseases [9].
B-cell targeting therapies are mainly based on the depletion of $B$ cells by depleting antibodies, such as rituximab, which targets $B$ cells via cell surface CD20. This treatment leads to long-lasting depletion of peripheral B cells [10]. There are, however, disadvantages to such treatment, as rituximab, for instance, has no effect on plasma cells, which do not express CD20. Moreover, indiscriminate depletion of CD20 expressing cells also affects tolerogenic CD20-expressing B cell subsets. Complete depletion of the B-cell compartment therefore comes with side effects, such as vulnerability for infections. Hence, there is a need for more refined modulation of B-cell activity in immune-mediated diseases.

Mesenchymal stem or stromal cells (MSC) have potent immunomodulatory properties and target the proliferation and differentiation of a variety of immune cells [11]. In particular, the effect of MSC on effector and regulatory $T$ cells has been widely studied [12]. MSC inhibit the proliferation of $\mathrm{T}$ cells via a plethora of mechanisms, including indoleamine 2,3-dioxygenase (IDO) activity [13], secretion of 
prostaglandin E2, TGF- $\beta$, and several other factors [14] and induce $T$ cells to adopt a regulatory function $[15,16]$. In addition, MSC suppress natural killer cell cytotoxic activity [17], inhibit dendritic cell maturation [18], and stimulate macrophage differentiation to regulatory macrophages with antiinflammatory function $[19,20]$.

There is evidence for interaction between MSC and B cells, although the available data are inconclusive from a mechanistic point of view [21]. MSC have been shown to inhibit the differentiation of $B$ cells stimulated by $T$ celldependent and independent antigens [22-24]. It is elusive whether the regulation of $B$ cells by MSC is mediated via direct effects on B cells or whether MSC regulate B cells via $T$ cells as intermediates. Furthermore, there is evidence that murine MSC induce B cells with cell surface markers associated with regulatory functions [25], and recently it has been shown that MSC induce $\mathrm{CD}^{+}$B cells with regulatory function in a clinical trial for graft versus host disease [26]. Insight into the functional interaction between human MSC and B cells is important for exploring the potential of MSC for refined modulation of B-cell functions.

In the body, MSC are widely distributed and can be found at sites where they encounter B cells, such as the bone marrow, lymph nodes, and tonsils [27]. At these sites, MSC may interact with $B$ cells to modulate initial or ongoing immune responses. Currently, culture-expanded MSC are under investigation for cellular immune therapy and have been tested in clinical trials for graft versus host disease [28], allograft rejection [29], and autoimmune diseases [30]. Upon administration, culture-expanded MSC may interact with B cells present at their homing site. In addition, administration of MSC is accompanied with systemic increases in a range of pro-inflammatory and anti-inflammatory cytokines, which may affect $B$ cells at distant sites [31].

In this study, interactions between human adipose tissuederived MSC (ASC) and human tonsil-derived B cells were examined. ASC promoted quiescent B-cell survival and modulated activated T-cell-mediated B-cell proliferation and differentiation into antibody-producing and regulatory B-cell subsets. The results of this study demonstrate that ASC play a regulatory role on B-cell function by targeting B cells directly, as well as indirectly via T cells.

\section{MATERIALS AND METHOdS}

\section{Isolation and Culture of Subcutaneous ASC}

Subcutaneous adipose tissue from healthy donors that became available as a waste product during the kidney donation procedure was collected after obtaining written informed consent as approved by the Medical Ethical Committee of the Erasmus University Medical Centre Rotterdam (protocol no. MEC-2006-190). The tissue was collected in minimum essential medium- $\alpha$ (MEM- $\alpha$ ) (Sigma Aldrich, St. Louis, MO, https://www. sigmaaldrich.com) supplemented with penicillin $(100 \mathrm{lU} / \mathrm{ml})$, streptomycin $(100 \mu \mathrm{g} / \mathrm{ml})(1 \% \mathrm{P} / \mathrm{S}$; Lonza, Verviers, Belgium, http://www.lonza.com/), and $2 \mathrm{mM}$ L-glutamine (Lonza) and stored at $4{ }^{\circ} \mathrm{C}$ for $3-16$ hours. ASC were isolated as described previously [32]. Cultures were kept at $37^{\circ} \mathrm{C}, 5 \% \mathrm{CO}_{2}$, and $95 \%$ humidity and refreshed twice weekly with $\mathrm{MEM}-\alpha$ with $1 \% \mathrm{P} / \mathrm{S}$, and $15 \%$ fetal bovine serum (FBS; Lonza). At $90 \%$ confluence, adherent cells were removed from culture flasks by incubation in $0.05 \%$ trypsin-EDTA (Life Technologies, Bleiswijk, The Netherlands, https://www.lifetechnologies.com/nl/en/home.html) at $37^{\circ} \mathrm{C}$ and cells were used for experiments described below or frozen at $-150^{\circ} \mathrm{C}$ until further use. ASC were used for experiments between passages 2 and 5 and their phenotypic markers and osteogenic and adipogenic potential were tested as described before [33]. ASC from 20 donors were used in the experiments in combination with the B cells and $T$ cells from tonsils from three different donors.

\section{Isolation of B and T Cells from Tonsils}

Tonsils were obtained after routine tonsillectomy (Sophia Children's Hospital, Erasmus MC, Rotterdam) and after written informed consent was given by the parents. The use of these tonsils for research purposes was approved by the Medical Ethical Committee of the Erasmus University Medical Center (protocol no. MEC-2013-093). All samples and data were analyzed anonymously. Tonsils from three different donors were used in the experiments to minimize variation at the B-cell level. Tonsils were processed to obtain a single-cell suspension. Mononuclear cells, isolated using density centrifugation, were stored at $-150^{\circ} \mathrm{C}$ until use. Upon thawing, quiescent $\mathrm{B}$ cells were isolated by negative selection using anti-CD43-magnetic beads (Miltenyi Biotec $\mathrm{GmbH}$, Bergisch Gladbach, Germany, http://www.miltenyibiotec. com/en/) [34].

$\mathrm{CD}^{+} \mathrm{T}$ cells were isolated by positive selection using anti-CD4-magnetic beads (Miltenyi Biotec) on the autoMACS (Miltenyi Biotec). Purity was determined by flow cytometry (FACS Canto II). Typically, cell suspensions consisted of $>98 \%$ pure $\mathrm{CD} 4^{+} \mathrm{T}$ cells or $\mathrm{CD} 19^{+} \mathrm{B}$ cells.

\section{Stimulation and Cell Subset Characterization}

B cells were cultured in Iscove's Modified Dulbecco's Medium (Lonza) with $\mathrm{CD}^{+}{ }^{+} \mathrm{T}$ cells stimulated with phorbol 12-myristate 13-acetate and ionomycin (PMA/iono; $50 \mathrm{ng} / 1 \mu \mathrm{g} / \mathrm{ml}$, Sigma Aldrich) or with a stimulation cocktail to mimic antigen and $\mathrm{T}$

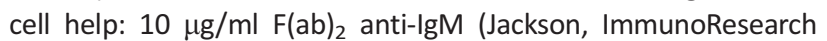
laboratories, Inc., West Grove. PA. www.jieurope.com), $10^{3} \mathrm{IU}$ IL-2 (Proleukin, Prometheus laboratories, Inc. San Diego, CA, http://prometheuslabs.com/), and $5 \mu \mathrm{g} / \mathrm{ml}$ anti-CD40 agonistic monoclonal antibody (Bioceros, Utrecht, The Netherlands, http://www.bioceros.com/home) for 10 days in a 96-well plate. Cells were collected and processed for flow cytometric analysis (FACS Canto II, Diva Software, BD Biosciences, San Jose, CA. https://www.bdbiosciences.com/), and supernatants were stored at $-80^{\circ} \mathrm{C}$ for immunoglobulin and cytokine determination. The antibodies used for flow cytometry phenotyping were: CD19-V500 (clone HIB19), CD27-PE-Cy7 (clone 0323), CD38-PE (clone HB7), Via Probe for viability, CD4-PacBlue (clone RPA-T4), CD90-APC (all from BD biosciences), and CD24-APC (clone SN3 A5-2H1D) (eBioscience, San Diego, CA, http://eu. ebioscience.com/). The immunophenotype of the B-cell subsets that were analyzed is defined in Table 1.

For intracellular staining, 12 hours before recovering the cells from the coculture, the protein transport inhibitor monensin (GolgiStop, BD Biosciences) was added to the wells (0.1 $\mu \mathrm{l} / 10^{5}$ cells/well). Cells were incubated with $20 \mathrm{mM}$ EDTA, washed, and stained for surface markers with CD19-V500, CD27-PE-Cy7, and Via Probe. Cells were then permeabilized 
using a Fixation/Permeabilization kit (eBioscience) and stained intracellularly with anti-IL-10-PE (clone JES3-9D7) (BD Pharmingen). Flow cytometric analysis was performed using the BD FACSCanto II flow cytometer and BD FACSDiva software (both BD Biosciences). Fluorescence minus one controls were used to set accurate gates for the intracellular staining.

\section{Apoptosis Analysis}

B-cell apoptosis was analyzed using a PE Annexin V Apoptosis Detection Kit (BD Pharmingen). In brief, cells were recovered from the cultures and washed twice with cold PBS and resuspended in binding buffer. Cells $\left(10^{5}\right)$ were transferred to a new tube and labeled with Annexin $V$ and 7AAD for 15 minutes and analyzed by flow cytometry.

\section{Blocking Experiments}

To assess the involvement of factors released by ASC on B-cell survival, we used the IL-6R blocking therapeutic antibody Tocilizumab [35] (125 $\mu \mathrm{g} / \mathrm{ml}$, RoActemra, Hoffmann-La Roche, Basel, Switzerland, http://www.actemra.com/) at a dose that is proven to fully block membrane-bound and soluble IL-6R. We also used the prostaglandin inhibitor indomethacin (10 $\mu \mathrm{M}$, Fluka Biochemika, Italy), BAFFR-Fc chimera, which blocks BAFF ( $1 \mu \mathrm{g} / \mathrm{ml}$, R\&D Systems, Minneapolis, MN. http:// www.rndsystems.com), and TACl-Fc chimera, which blocks both BAFF and APRIL (1 $\mu \mathrm{g} / \mathrm{ml}$ Enzo Life Sciences, Lausen, Switzerland, http://www.enzolifesciences.com/). These concentrations are known to neutralize recombinant BAFF and/or APRIL up to $100 \mathrm{ng} / \mathrm{ml}$ [36].

\section{Transwell Cultures}

To study contact-dependent interactions between ASC and B cells, ASC were seeded in 12-well plates separated from B cells by $0.4 \mu \mathrm{m}$ pore membranes (Greiner Bio-one, Alphen aan den Rijn, The Netherlands. http://www.greinerbioone.com). After 10 days of coculture, B cells were collected and processed for further analysis.

\section{Proliferation Assay}

$B$ and $T$ cells were labeled with carboxyfluorescein succinimidyl ester (Life Technologies, Bleiswijk, The Netherlands. http://www.lifetechnologies.com) before coculture with ASC and/or stimulation. At day 10, the cells were recovered and washed before analyzing the number of divisions using fluorescence dilution assessed by flow cytometry. The percentage of cells per generation was analyzed using FlowJo Software 7.7 (Treestar, Ashland, OR, http://www.flowjo.com/).

\section{Immunoglobulin G ELISA}

Reduced-surface 96-well plates (Corning Costar, Amsterdam, The Netherlands. http://www.corning.com/) were coated with goat anti-human $\lg (\operatorname{IgM}+\lg G+\operatorname{IgA}, \mathrm{H}+\mathrm{L})$ (Southern Biotech, Birmingham, AL, www.southernbiotech.com) overnight. Diluted supernatants and standard (Sigma-Aldrich) were added to the plates and incubated for 90 minutes. Goat antihuman IgG-HRP (My Biosource, San Diego, CA) was used as a conjugate and 3,3',5,5'-tetramethylbenzidine (KPL, Gaithersburg, MD, www.kpl.com) as a chromogenic substrate. Absorbance was read at $595 \mathrm{~nm}$ using a Wallac Victor2 1420 multilabel plate reader (Perkin Elmer, Waltham, MA. http:// www.perkinelmer.com).

\section{Measurement of Cytokine Secretion}

Supernatants from the cocultures kept at $-80^{\circ} \mathrm{C}$ were thawed and used for measurement of cytokine levels. IL-10, IL-6, and IFN- $\gamma$ were quantified in the supernatant using a Milliplex kit (Merck Millipore, Amsterdam, The Netherlands. http://www. merckmillipore.com) according to manufacturer's instructions. Briefly, $25 \mu \mathrm{l}$ of cell culture supernatant was assayed in duplicate. Human cytokine standards were provided by the kit and a standard curve was prepared from $10,000 \mathrm{pg} / \mathrm{ml}$ to $3.2 \mathrm{pg} / \mathrm{ml}$. Samples and standards mixed with antibody-coated magnetic beads were incubated overnight in a 96-well plate at $4^{\circ} \mathrm{C}$ under continuous agitation. Plates were washed and incubated with detection antibodies for 1 hour. Finally, plates were washed and incubated with streptavidin-phycoerythrin for 30 minutes. Mean fluorescence was analyzed on a Luminex and cytokine concentrations calculated with Luminex software.

\section{RNA Expression Quantification}

ASC were seeded in six-well plates at a density of $1 \times 10^{5}$ per well in the presence of $1 \times 10^{6} \mathrm{~B}$ cells with or without a stimulation cocktail to mimic T-cell help $\left(10 \mu \mathrm{g} / \mathrm{ml} \mathrm{F}(\mathrm{ab})_{2}\right.$ anti$\mathrm{IgM}, 10^{3} \mathrm{IU} \mathrm{IL-2}$, and $5 \mu \mathrm{g} / \mathrm{ml}$ agonistic anti-CD40). After 10 days, $B$ cells were recovered, pelleted in phosphate buffered saline (PBS)- Diethylpyrocarbonate, and snap frozen. RNA was isolated and $500 \mathrm{ng}$ was used for cDNA synthesis as described previously [37]. Gene expression was determined by real-time RT-PCR using universal PCR master mix (Life Technologies) and an Assay-on-demand for IL-10 (Hs00174086.m1) (Applied Biosystems, Foster City, CA, http://www.appliedbiosystems.com) and analyzed on an ABI PRISM 7700 sequence detector (Applied Biosystems). Data are expressed as relative copy number of the PCR products with respect to the housekeeping gene GAPDH. Relative copy number was calculated using the formula $2(40-\mathrm{Ct}$ value).

\section{Fluorescence-Activated Cell Sorting and Functional Characterization of B-Cell Subsets}

Stimulated B cells cocultured with ASC at a ratio of 5:1 for 10 days were recovered from the plates, washed with PBS $+1 \%$ FBS, and labeled with CD19-V500, CD38-Pacific Blue (clone HIT2), Via Probe for viability and CD24-APC (eBioscience). Bcell subsets were isolated by FACSAria-Il (Becton Dickinson). Viable $\left(7 A A D^{-}\right) C D 19^{+} B$ cells were separated in three subsets: $\mathrm{CD} 38^{\text {high }} \mathrm{CD} 24^{\text {high }}, \mathrm{CD} 38^{\text {Int }} \mathrm{CD} 24^{\text {Int }}$, and $\mathrm{CD} 38^{-} \mathrm{CD} 24^{\text {high }}$.

Isolated subsets were kept overnight at $37^{\circ} \mathrm{C}$ with $5 \mu \mathrm{g} / \mathrm{ml}$ anti-CD40 agonistic monoclonal antibody (Bioceros). The next day, $50 \mathrm{ng} / 1 \mu \mathrm{g} / \mathrm{ml} \mathrm{PMA} /$ lono and $0.1 \mu \mathrm{l} / 10^{5}$ cells of Golgi Plug (BD Biosciences) were added for 5 hours. Cells were then labeled with CD19-V500, CD38-Pacific Blue, Via Probe for viability, and CD24-APC (eBioscience) and IL-10-PE (BD Pharmingen). Flow cytometric analysis was performed using the BD FACSCanto II flow cytometer and BD FACSDiva software.

\section{Statistical Analysis}

Data represent mean $\pm S D$. Statistical analyses were performed by means of paired $t$ tests using GraphPad Prism 5 software (GraphPad Software, San Diego, CA, http://www. graphpad.com/). A two-tailed $p$-value $<0.05$ was considered statistically significant. 

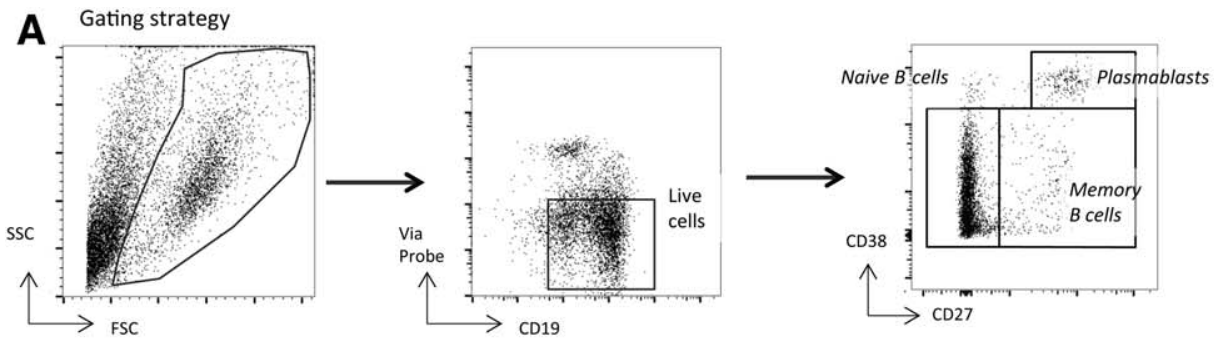

B
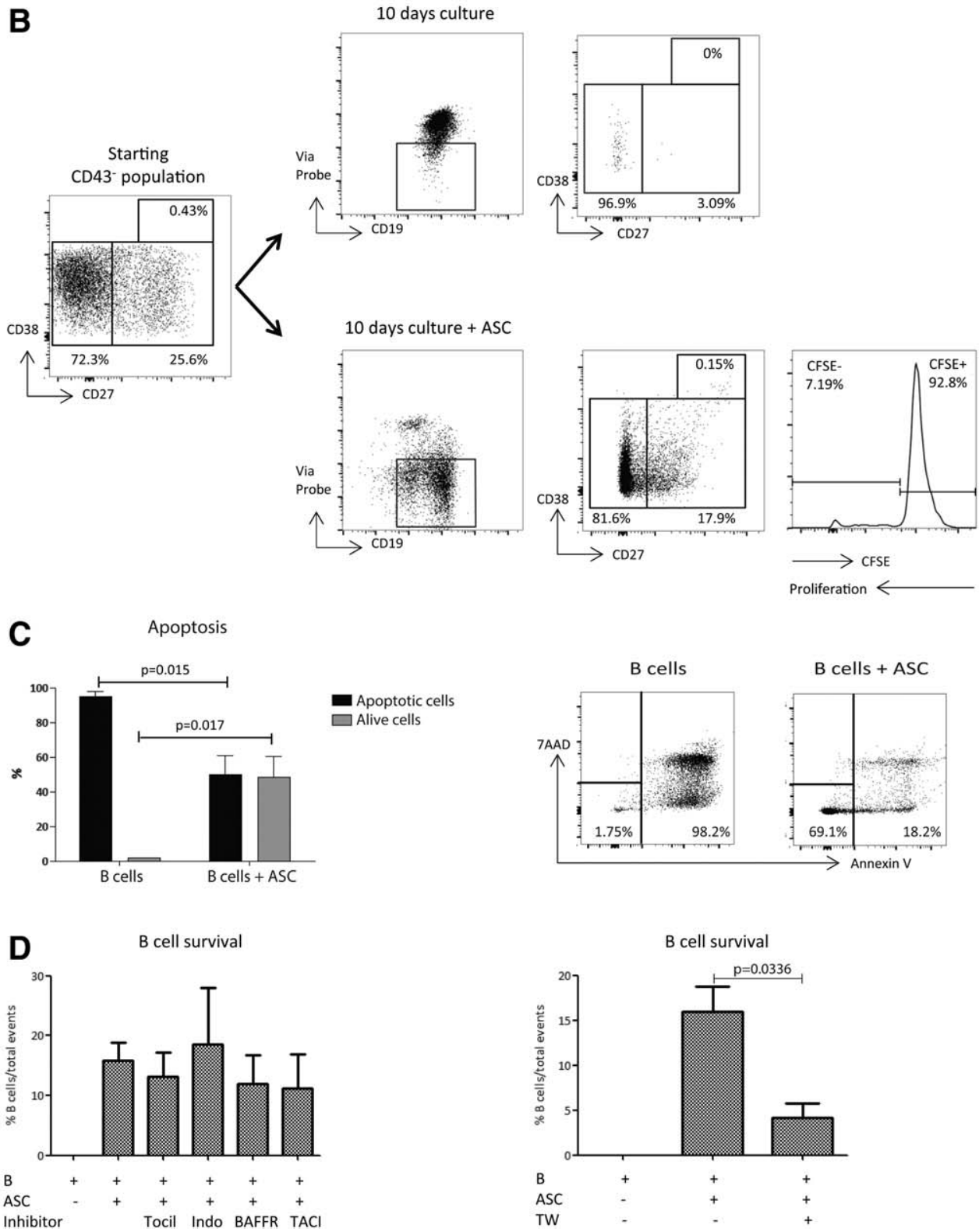

Figure 1. ASC support B-cell survival. (A): The gating strategy to analyze the B-cell subsets was based on the viability marker Via probe and CD19 to obtain live B cells, which were then gated for CD27 and CD38 to obtain naive, memory, and plasmablast subsets. (B): The starting population was mostly composed of naïve B cells $(<70 \%)$. After 10 days in culture, B cells showed poor survival unless they were cocultured with ASC (ratio B cells to ASC 5:1). In the presence of ASC, B-cell survival improved, while the B-cell subset composition did not change and B cells did not proliferate. (C): ASC promote B-cell survival by significantly inhibiting apoptosis of unstimulated B cells. The right panel shows a representative Annexin V/7AAD fluorescence-activated cell sorting plot of the apoptosis analysis. (D): Different blockers were tested to identify or exclude pathways involved in B-cell survival. IL6R blocker (Tocil), prostaglandin inhibitor (Indo), BAFF, and TACl decoy receptors (APRIL) were added to ASC-B-cell cocultures. None of the blockers reduced ASC-mediated survival of B cells. When ASC were physically separated from B cells by a $0.4 \mu \mathrm{m}$ transwell membrane (TW) B-cell survival dropped threefold. Means \pm SD shown. Abbreviations: ASC, adipose tissue-derived mesenchymal or stromal stem cells; CFSE, carboxyfluorescein succinimidyl ester. 
Table 1. Immunophenotypes of B-cell subsets and mesenchymal or stromal stem cells

\begin{tabular}{|c|c|c|}
\hline Cell population & Phenotype & Reference \\
\hline Naive B cells & $\mathrm{CD}_{19}{ }^{+} \mathrm{CD} 27^{-} \mathrm{CD}_{3} 8^{-/ \mathrm{Int}}$ & [39] \\
\hline Memory B cells & $\mathrm{CD} 19^{+} \mathrm{CD} 27^{+} \mathrm{CD} 38^{-/ \mathrm{Int}}$ & [39] \\
\hline Plasmablasts & $\mathrm{CD} 19^{+} \mathrm{CD} 27^{\text {high }} \mathrm{CD} 38^{\text {high }}$ & [39] \\
\hline Transitional B cells & $\mathrm{CD}_{1} 9^{+} \mathrm{CD} 27^{-} \mathrm{CD} 38^{\text {high }} \mathrm{CD} 24^{\text {high }}$ & [41] \\
\hline Regulatory B cells & $\mathrm{CD} 19^{+} \mathrm{CD} 27^{-} \mathrm{CD}_{3} 8^{\text {high }} \mathrm{CD} 24^{\text {high }} \mathrm{IL} 10^{+}$ & [41] \\
\hline Mesenchymal stem cells & $\mathrm{CD} 45^{-} \mathrm{CD}{ }^{+} \mathrm{CD} 3^{+} \mathrm{CD} 105^{+} \mathrm{HLA}-\mathrm{I}^{\text {int }} \mathrm{HLA}-\mathrm{II}^{-} \mathrm{CD}{ }^{-} \mathrm{CD}^{-} 6^{-}$ & [37] \\
\hline
\end{tabular}

This table summarizes the phenotype and markers used to characterize the cells and subsets used in the study.

\section{RESULTS}

\section{ASC Support B-Cell Survival}

ASC showed the immunophenotype defined by the International Society for Cellular Therapy [38]. The cells obtained from human tonsils after CD43 depletion by magnetic cell sorting were $>98 \%$ quiescent B cells, depleted of activated B cells, B1 cells, and plasma cells, as described previously [34, 39]. The cells were analyzed by flow cytometry and B-cell subsets were defined according to the gating strategy depicted in Figure $1 \mathrm{~A}[40]$. The $B$ cells obtained were mainly naïve $B$ cells and memory $B$ cells with less than $1 \%$ plasmablasts (for an overview of ASC and B-cell subset immunophenotypes refer Table 1). B cells did not survive culturing for 10 days without supplemental stimulation. However, coculture with ASC supported B-cell survival (Fig. 1B). ASC kept B cells in a nonproliferating state and did not change the proportions of naive $B$ cells, memory B cells, and plasmablasts (Fig. 1B) indicating that ASC do not preferentially increase the survival of a specific B-cell subset.

ASC promoted the survival of B cells by hampering apoptotic cell death (Fig. 1C). To further investigate the role of ASC in the survival of unstimulated B cells, blockers were added to some of the main factors that are secreted by ASC and that are believed to be involved in B-cell survival, which include IL-6, PGE-2, BAFF, and APRIL [41-44]. The IL-6 receptor blocker tocilizumab, the PGE-2 production inhibitor indomethacin, the decoy receptors BAFFR-FC and TACI-FC (BAFF and APRIL blocking) did not reduce B-cell survival. Conversely, when B cells were separated from ASC by a transwell system that allowed passage of soluble factors, there was a reduction in B-cell survival from $15.9 \%( \pm 2.8)$ to $4.1 \%$ ( \pm 1.6$)$ (Fig. 1D). These results indicate that the effect of ASC on B-cell survival is at least partially cell contact dependent.

\section{ASC Inhibit Differentiation and Proliferation of B Cells Stimulated by $\mathrm{CD}^{+}{ }^{+} \mathrm{T}$ Helper Cells}

To examine the effect of ASC on T cell-mediated B-cell proliferation and differentiation, $B$ cells were cocultured for 10 days with PMA/ionomycin stimulated $\mathrm{CD} 4^{+} \mathrm{T}$ helper cells at a ratio of 5:1 (Fig. 2). In the presence of ASC, the differentiation of $B$ cells into plasmablasts $\left(\mathrm{CD} 19^{+} \mathrm{CD} 27^{\text {high }} \mathrm{CD} 38^{\text {high }}\right)$ was strongly decreased from $4.76 \%$ to $0.054 \%$. The reduction of $B$ cell differentiation into antibody-producing cells by ASC was corroborated by reduced levels of IgG in the cell culture supernatant (Fig. 2A). In the same setting, B as well as T-cell proliferation was reduced by ASC (Fig. 2B). These observations raised the question whether the effect of ASC on B-cell differentiation and proliferation was mediated via a direct interac- tion between ASC and B cells or whether these effects were a result of the effects of ASC on T cells.

\section{ASC Have a Direct Effect on B-Cell Differentiation But Not Proliferation}

To examine whether ASC directly targeted B cells, B cells were stimulated in the absence of T cells with an antibody/ cytokine cocktail to mimic antigen and T-cell help. This was achieved by crosslinking of the BCR via low-dose anti-IgM, provision of costimulation by a CD40 agonist [45], and cytokine support for proliferation by IL-2 [46]. This stimulation cocktail led to plasmablast formation and IgG production (Fig. 3A). ASC inhibited B-cell differentiation into plasmablasts in this setting, indicating that ASC act directly on B cells to inhibit differentiation into plasmablasts. This effect was observed at ratios of 1:5 and 1:25. IgG production was more effectively reduced at 1:5 ratio. Similarly to what we observed under unstimulated conditions, ASC support survival, and reduce apoptosis of $B$ cells under $T$ cell-like cocktail stimulation (Fig. 3B).

Activation with anti-IgM, CD40 agonist, and IL-2 also led to B-cell proliferation. B-cell proliferation was not affected by ASC at ratios $1: 5$ or 1:25 (Fig. $3 C$ ), indicating that the inhibition of B-cell proliferation by ASC previously observed was mediated via T cells.

The antiproliferative effect of ASC on T cells depends on activation of ASC by IFN- $\gamma$ [47]. To study whether the inhibition of B-cell proliferation by ASC was dependent on IFN- $\gamma$ secretion by T cells, IFN- $\gamma$ levels in the supernatants of cocultures of ASC and B cells with or without activated T cells were analyzed. IFN- $\gamma$ was only detected in the presence of T cells (Fig. 3D), suggesting that IFN- $\gamma$ secretion by $T$ cells is responsible for activation of the antiproliferative capacity of ASC.

\section{Inhibition of B-Cell Differentiation by ASC Is Independ- ent of IL-6}

IL-6 plays a diverse role in the immunomodulatory effect of ASC and is one of the most abundantly secreted factors by ASC [48]. The ASC secreted high levels of IL-6 under control conditions (5749.14 $\pm 1545.6 \mathrm{pg} / \mathrm{ml})$, which further increased upon coculture with activated B cells (B cells + Stimuli + ASC: $8118.8 \pm 70.5$ ) or $B$ cells activated by $T$ cells (B cells + activated $T$ cells + ASC: $8136.8 \pm 443.8$ ) (Fig. $3 E$ ). To assess whether IL-6 played a role in the inhibition of plasmablast formation by ASC, the IL-6R blocker tocilizumab was added to the cocultures. Blocking engagement of the IL-6R receptor did not abolish the effect of ASC on plasmablast formation (Fig. $3 F$ ), indicating that the reduction of $B$ cell differentiation by ASC is IL-6 independent. 
A

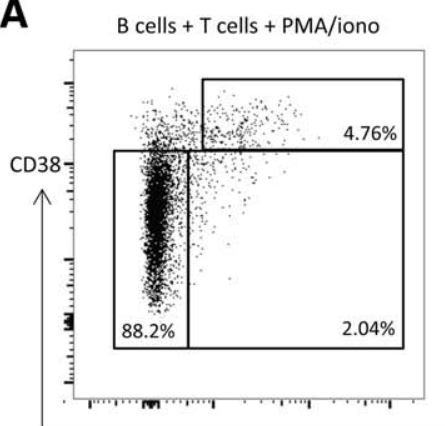

$B$ cells + T cells + PMA/iono + ASC

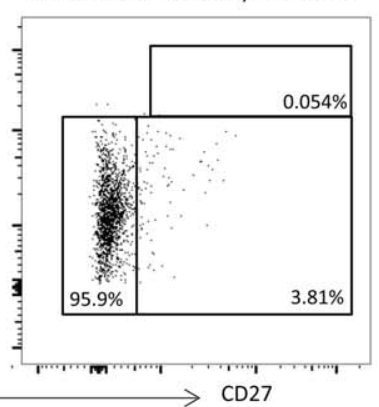

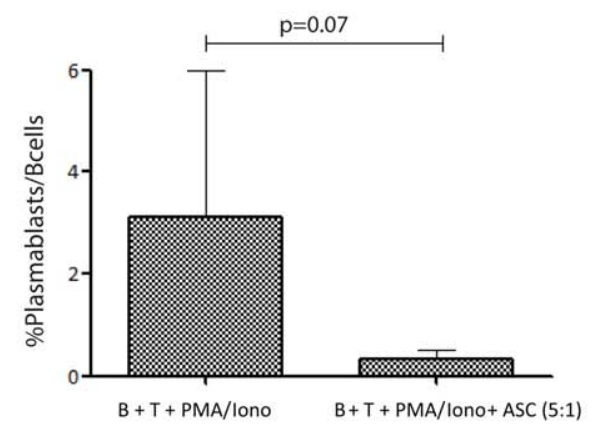

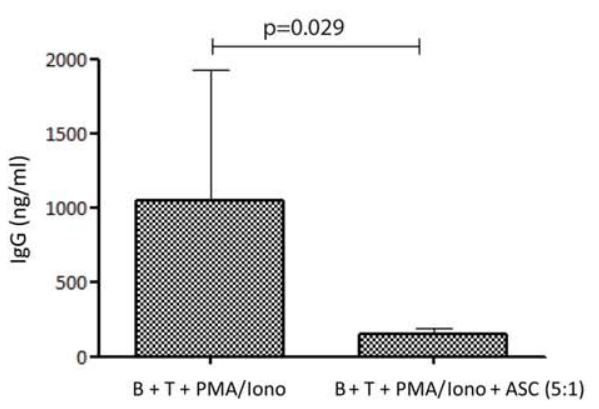

B

B cell proliferation
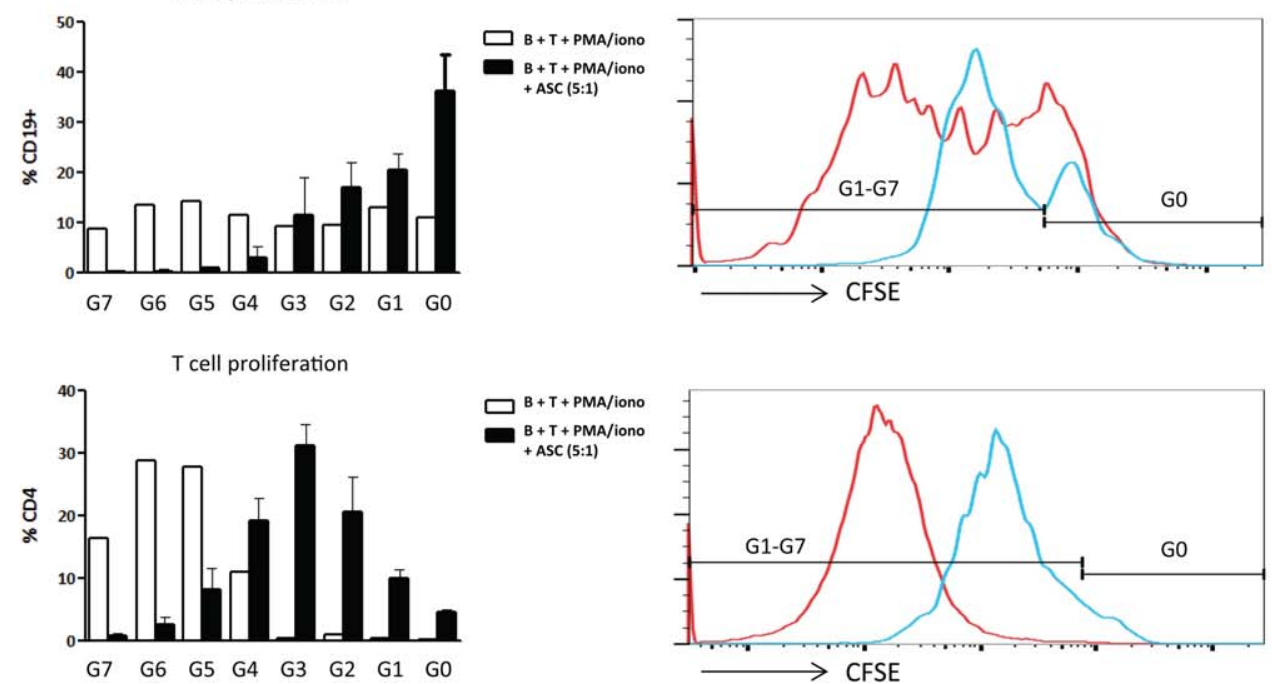

Figure 2. ASC inhibit B-cell differentiation and proliferation induced by activated T helper cells. (A): B cells cocultured with PMA/ionomycin activated T cells (ratio B cells to T cells $5: 1$ ) were induced to differentiate into $\mathrm{CD} 38^{\text {high }} \mathrm{CD} 27^{\text {high }}$ plasmablasts. The presence of ASC reduced B-cell differentiation. The top row shows representative plots and the bottom row the percentage of plasmablasts obtained in four different experiments and the corresponding IgG concentrations in the culture supernatants. The production of IgG correlated with the plasmablast percentages. (B): Proliferation was assessed through carboxyfluorescein succinimidyl ester label dilution by B cells (top row) and T cells (bottom row). Representative overlay plots are shown on the right and proliferation analysis of four different experiments shown in the graphs on the left. G0 represents the percentage of nonproliferated cells, G1 represent cells in the first cell division, and so forth. Red lines represent the proliferation of B and T cells in the coculture and the blue lines show the proliferation of the same cells in the presence of ASC. Abbreviations: ASC, adipose tissue-derived mesenchymal or stromal stem cells; CFSE, carboxyfluorescein succinimidyl ester; PMA, phorbol 12-myristate 13-acetate.

\section{ASC Increase the Percentage of $\mathrm{CD} 19^{+} \mathrm{CD} 27^{-} \mathrm{CD} 38^{\text {high }}$ B Cells}

When $B$ cells were stimulated with a cocktail to mimic T-cellhelp (anti-IgM + anti-CD40 + IL-2) and cocultured with ASC there was an increase in the percentage $\mathrm{CD} 27^{-} \mathrm{B}$ cells and a concomitant trend in a reduced percentage of $\mathrm{CD} 27^{+} \mathrm{B}$ cells (Fig. 4A). The increase in $\mathrm{CD}^{-} 7^{-} \mathrm{B}$ cells was due to an increase in the percentage of $\mathrm{CD} 19^{+} \mathrm{CD} 27^{-} \mathrm{CD} 38^{\text {high }} \mathrm{B}$ cells, among which we encounter $B$ cells with regulatory capacity (Fig. 4B).

\section{ASC Induce Regulatory B Cells}

Recently a population of $B$ cells with regulatory function was described based on the surface expression of CD24 and CD38 and IL-10-producing capacity $\left(\mathrm{CD} 19^{+} \mathrm{CD} 24^{\text {high }} \mathrm{CD} 38^{\text {high }} \mathrm{IL}-10^{+}\right)$ 

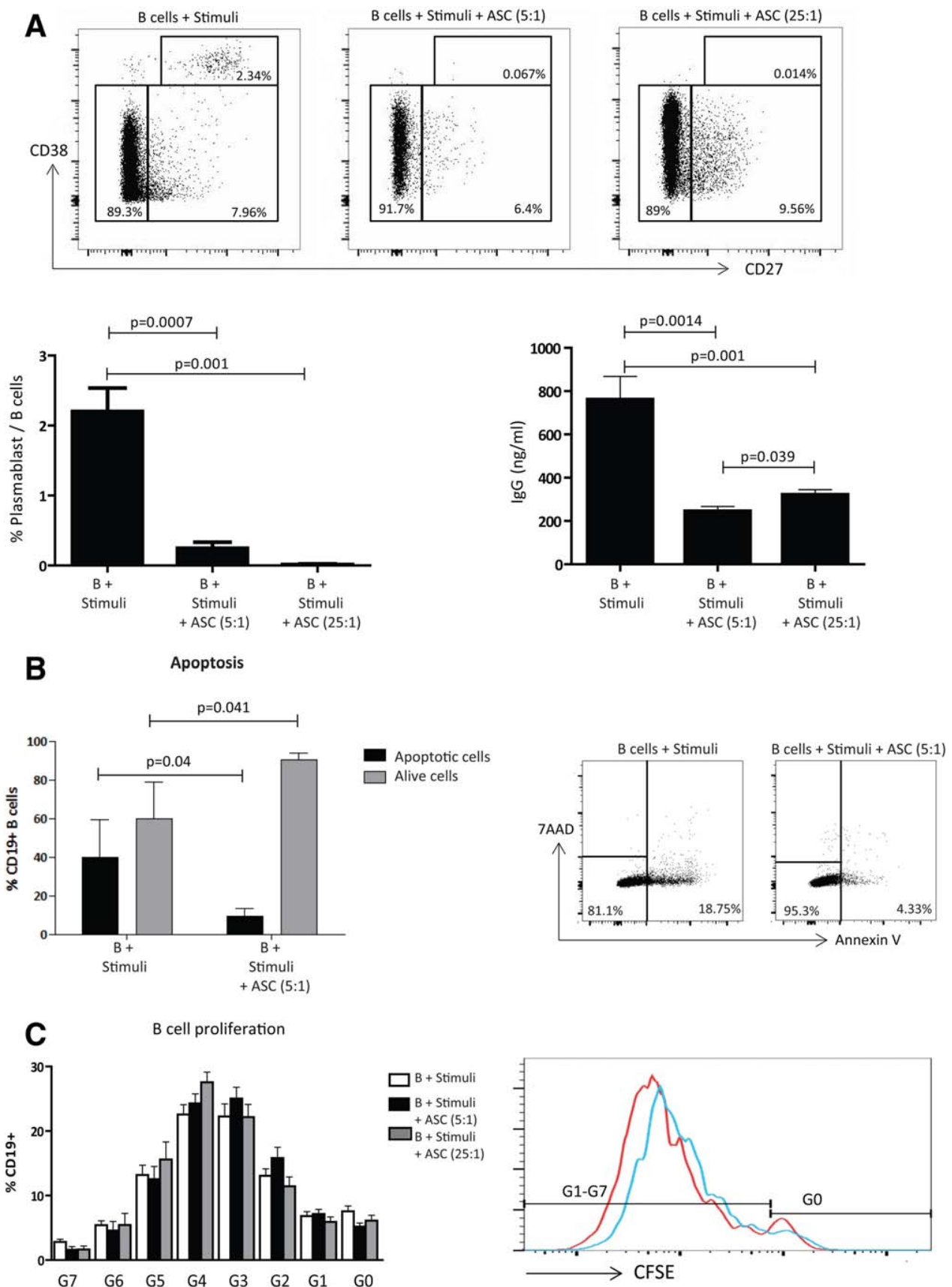

Figure 3. ASC have a direct effect on the inhibition of B-cell differentiation but not proliferation. (A): B cells stimulated with antiIgM + agonist anti-CD40 + IL-2 (Stimuli) to mimic T-cell help are induced to differentiate into plasmablasts. The presence of ASC limited B-cell differentiation. The top row shows representative plots and the bottom row the percentage of plasmablasts obtained in six different experiments and the accompanying IgG concentrations. The production of IgG correlated with the plasmablast percentages. (B): Apoptosis of B cells was assessed by Annexin V 7AAD staining. ASC at a ratio of 1:5 significantly reduced stimulated B cells apoptosis. Representative plots are shown. (C): Proliferation was assessed by carboxyfluorescein succinimidyl ester label dilution on B cells (top row). Representative overlay plots are shown on the right and proliferation analysis of four different experiments shown in the graphs of the left. G0 represents the percentage of nonproliferated cells, G1 represent the first cell division, and so forth. The red line represents the proliferation of B cells in the absence of ASC and the blue line shows the proliferation in the presence of ASC. (D): IFN- $\gamma$ secretion was analyzed in the supernatants of the coculture of B cells + activated $T$ cells or B cells stimulated with anti-IgM + agonist anti-CD40 + IL-2 (B+) in the presence or the absence of ASC. IFN- $\gamma$ was only secreted in the wells that contained activated T cells. (E): ASC secreted high levels of IL-6 in the supernatants. Coculture with stimulated B cells and B + activated T cells did not significantly change IL-6 levels. (F): Blocking of IL-6 binding to its receptor with tocilizumab had no effect on the reduction of differentiation of B cells into plasmablasts by ASC, neither in the presence of activated T cells nor upon anti-lgM + agonist anti-CD40 + IL-2 stimulation (Stimuli). Abbreviations: ASC, adipose tissue-derived mesenchymal or stromal stem cells; CFSE, carboxyfluorescein succinimidyl ester; PMA, phorbol 12-myristate 13-acetate. 
D

IFN $\gamma$ total

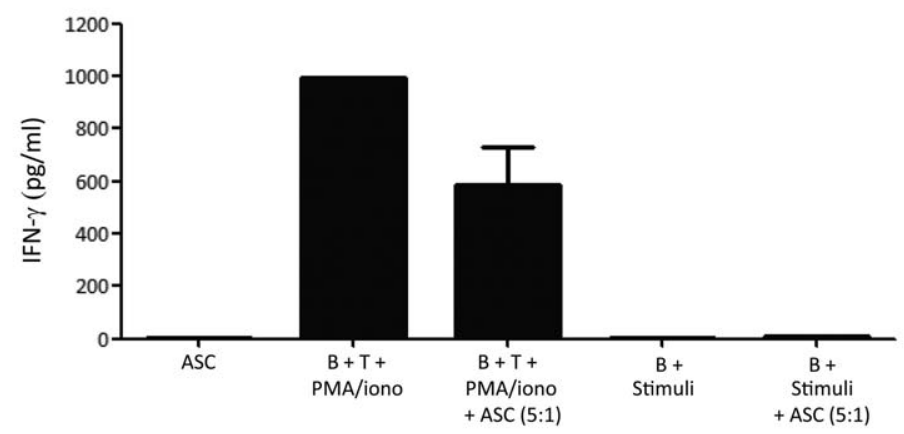

E

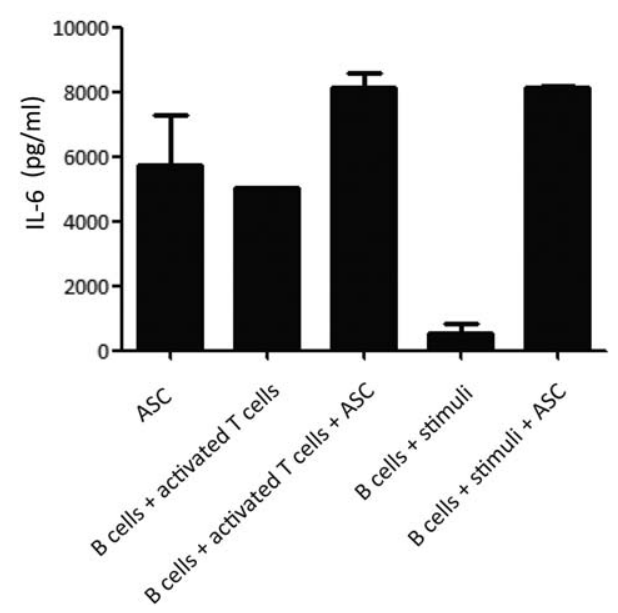

$\mathbf{F}$

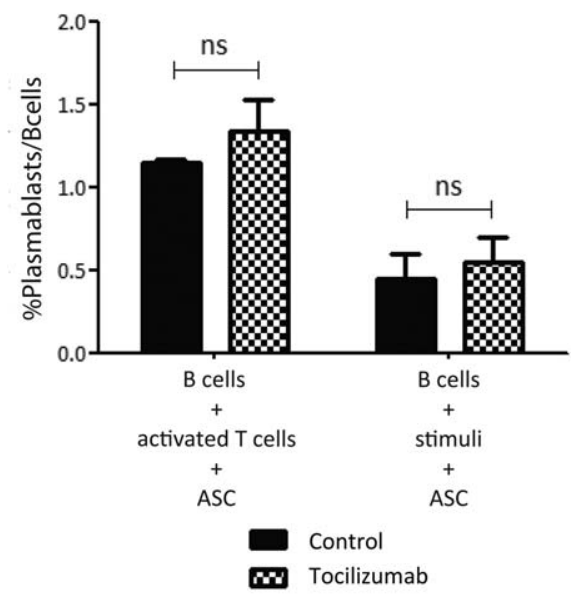

Figure 3. Continued.

A
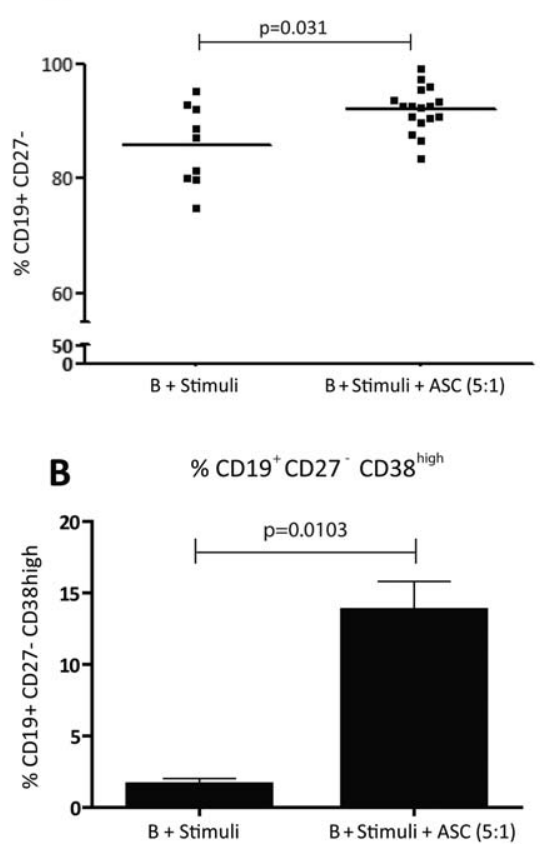

$\mathrm{CD} 27^{+} \mathrm{B}$ cells

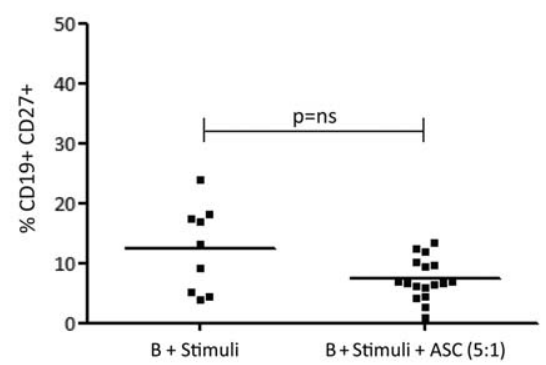

Figure 4. ASC increase the percentage of naïve $B$ cells. (A): ASC affect the balance between $C D 27^{-}$and $C D 27^{+} B$ cells by increasing the percentage of $C D 27^{-}$B cells. (B): This increase was mainly associated with an increase in the CD38 ${ }^{\text {high }}$ subpopulation. Representative plots of the effect of ASC on CD38 expression on $\mathrm{CD}_{2} 7^{-}$B cells are shown. Abbreviation: ASC, adipose tissue-derived mesenchymal or stromal stem cells. 

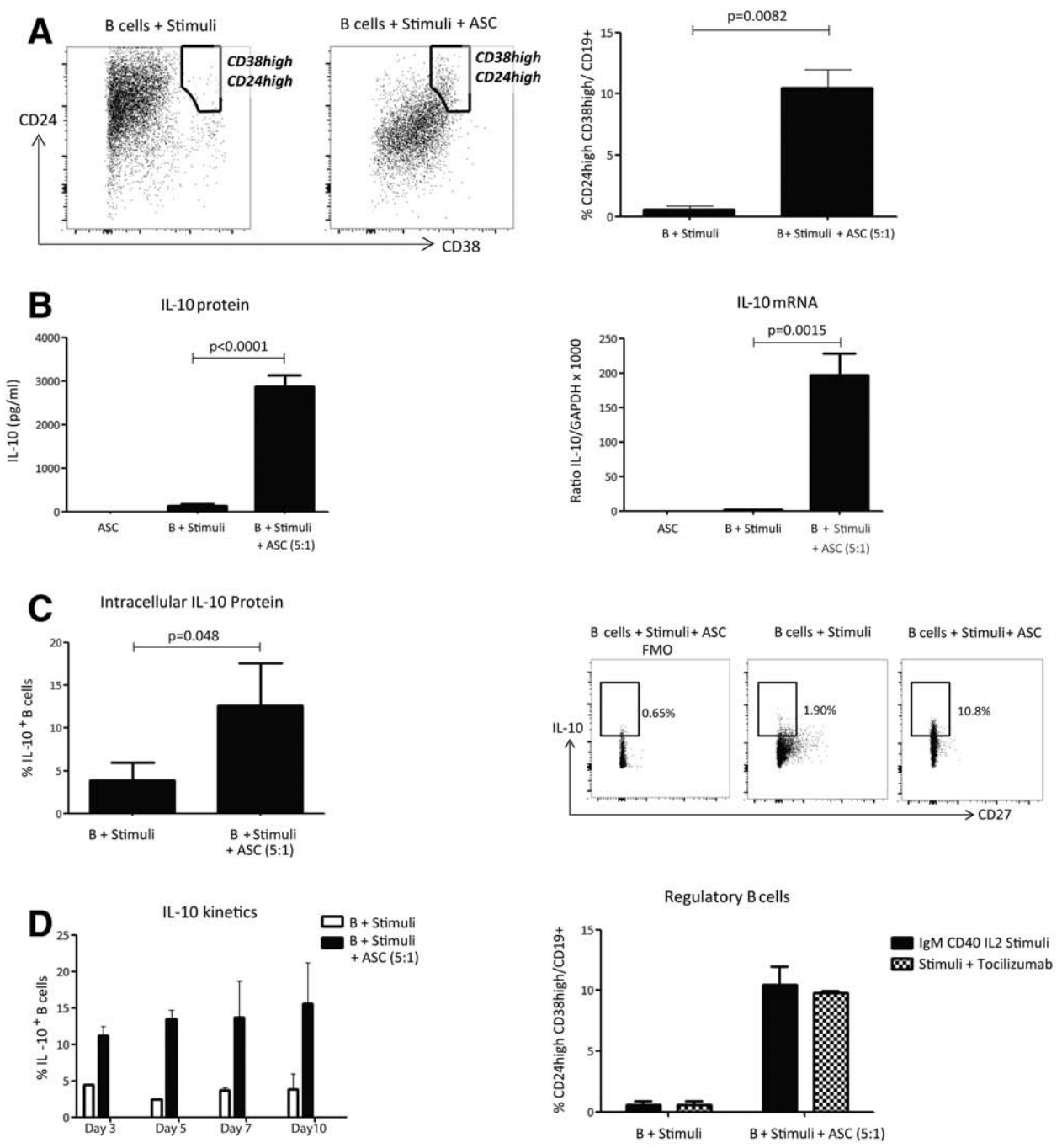

E Intracellular IL-10 Protein in sorted fractions
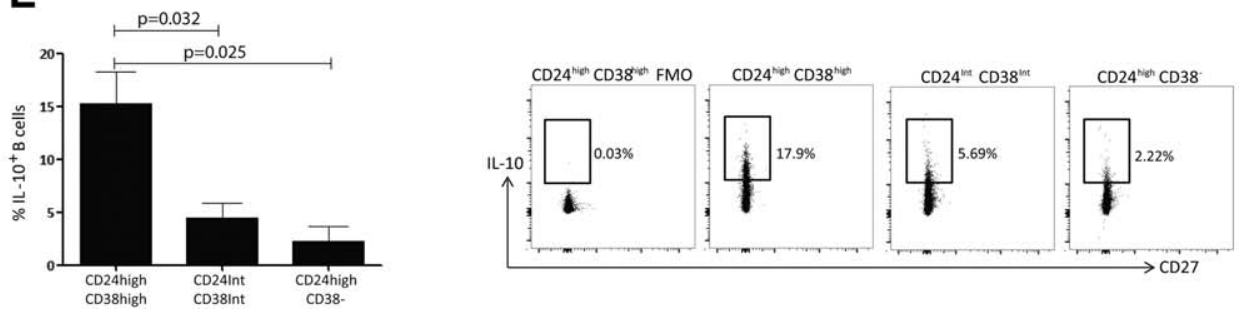

Figure 5. ASC induce regulatory $B$-cell formation. (A): $A S C$ induce $C D 19^{+} C D 38^{\text {high }} C D 24^{\text {high }} B$ cells, a phenotype consistent with regulatory B-cell function. (B): The increase in $\mathrm{CD} 19^{+} \mathrm{CD} 38^{\text {high }} \mathrm{CD} 24^{\text {high }} \mathrm{B}$ cells in the presence of ASC was correlated with increased levels of $\mathrm{IL}-10$ in coculture supernatants and with $\mathrm{IL}-10$ gene expression in B cells. (C): The percentage of IL-10-producing CD19 ${ }^{+}$cells was increased by ASC. Representative plots show the increased IL-10 intracellular staining in B cells after coculture with ASC. (D): The upregulation of $\mathrm{IL}-10^{+} \mathrm{CD} 19^{+}$cells by ASC was already evident after 3 days of coculture and remained at equivalent levels until day 10 (left graph). The IL-6R blocker Tocilizumab did not abrogate regulatory B-cell formation by ASC (right graph). (E): The production of IL-10 was mainly observed among the CD24 ${ }^{\text {high }} C D 38^{\text {high }}$ sorted cells. While there are IL-10-producing B cells in the CD24 $4^{\text {Int }}$ CD $38^{\text {lnt }}$, they are almost inexistent in the $\mathrm{CD} 24^{\text {high }} \mathrm{CD} 38^{-}$fraction. The right panel shows $\mathrm{FMO}$ as a gating control and representative plots of the sorted fractions. Abbreviations: ASC, adipose tissue-derived mesenchymal or stromal stem cells; FMO, fluorescence minus one.

$[49,50]$. We used these markers to study the potential induction of regulatory B cells by ASC (Fig. 5A).

$B$ cells stimulated by the cocktail demonstrated around $0.6 \% \pm 0.3 \%$ of regulatory $B$ cells while in the presence of ASC this percentage was increased to $10.5 \% \pm 1.5 \%$ (Fig. $5 \mathrm{~A}$ ). The main characteristic of regulatory $B$ cells is the expression of IL-10, which is assumed to be responsible for their regulatory function. We studied IL-10 secretion by B cells by analyzing coculture supernatants ASC did not secrete IL-10 and stimulated B cells produced very low levels of IL-10 (Fig. 5B). However, in the presence of ASC, IL-10 levels were significantly increased. The increased levels of IL-10 were associated 


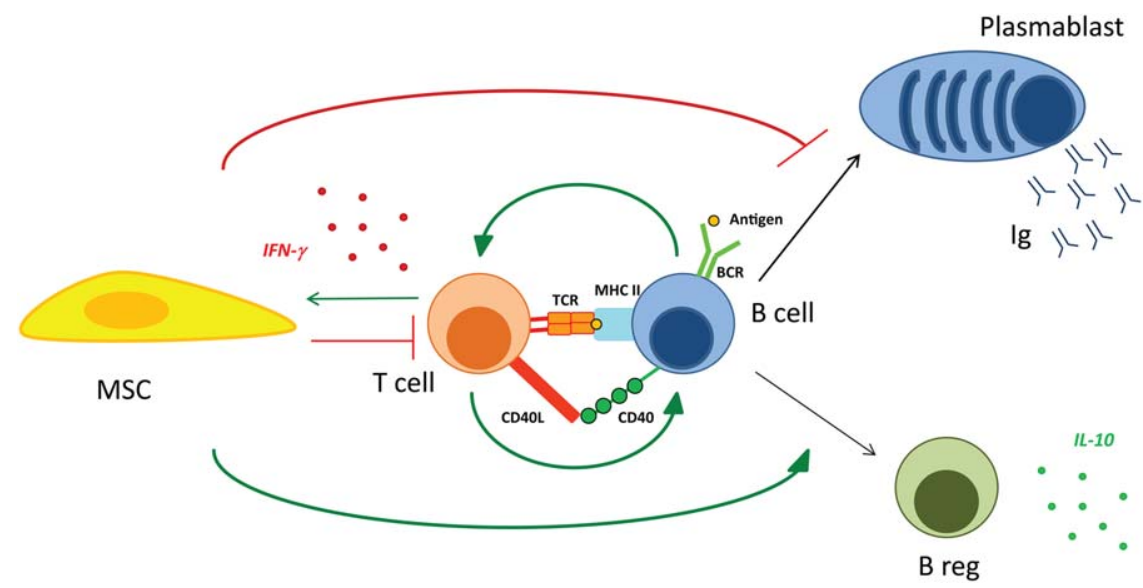

Figure 6. Model of the interactions between adipose tissue-derived MSC (ASC), B cells, and T cells. ASC have an inhibitory effect on plasmablast differentiation and a stimulatory effect on regulatory B-cell formation, independently of $\mathrm{T}$ cells. The inhibition of B-cell proliferation is mediated via T cells. Abbreviation: MSC, mesenchymal or stromal stem cells.

with increased IL-10 mRNA levels in B cells cocultured with ASC (Fig. 5B).

To demonstrate IL-10 protein production in B cells upon coculture with ASC, intracellular staining for IL-10 was performed (Fig. 5C). The percentage of IL-10-producing B cells increased from $3.4 \%$ under control conditions to $15.7 \%$ in the presence of ASC. The upregulation of IL-10-producing B cells was already detectable after 3 days of coculture and was maintained up to day 10 (Fig. 5D).

Finally, we investigated whether we could isolate the IL10-producing B cells with potential therapeutic application based on their cell surface phenotype. We analyzed the capacity of sorted regulatory B cells to produce IL-10 in comparison with other B-cell fractions: $\mathrm{CD} 19^{+} \mathrm{CD} 24^{\mathrm{Int}} \mathrm{CD} 38^{\mathrm{Int}}$ (primarily mature $\mathrm{B}$ cells) and $\mathrm{CD} 19^{+} \mathrm{CD} 24^{\text {high }} \mathrm{CD} 38^{-}$(primarily mature memory $B$ cells) [49] after a 5 hours restimulation with PMA/lono. The number of IL-10-producing cells was significantly higher in the $\mathrm{CD} 19^{+} \mathrm{CD} 24^{\text {high }} \mathrm{CD} 38^{\text {high }}$ regulatory B-cell subset than in the other subsets (Fig. 5E). This shows that we can induce regulatory B cells by ASC and purify them by fluorescence-activated cell sorting.

\section{DISCUSSION}

This article addressed how ASC affect proliferation, differentiation, and function of B cells. We found that ASC exert an indirect effect on B-cell proliferation through immunomodulation of $T$ cells and a direct effect on $B$ cells by inhibiting plasmablast differentiation and induction of IL-10-producing regulatory $B$ cells.

ASC supported the survival of $B$ cells partially in a contact-dependent manner, which is in line with the observations of others [23] who described a cell cycle arrest of B cells when cocultured with ASC. Thus, in the absence of antigen stimulation, ASC maintain B cells in a quiescent state and keep B-cell subset composition unchanged. This effect associates well with the stromal origin of ASC, where they maintain tissue and immune homeostasis [51].

Regarding the effect of ASC on activated B cells, some controversy exists on the effect of ASC on B-cell proliferation and differentiation (reviewed in [21]). The varying results obtained in different studies may be explained by different stimulation methods and by the B-cell source used. This study focused on T-cell-dependent B-cell responses, which play a major role in the progression of some autoimmune diseases and in organ transplant rejection. As a source of $\mathrm{B}$ cells, $\mathrm{CD} 43^{-}$untouched $B$ cells were isolated from tonsils. The use of $\mathrm{CD}_{4} 3^{-}$B cells from tonsils has the advantage that large numbers of quiescent $B$ cells can be isolated, which improves the reproducibility of results and offers potential for uniform stimulation.

ASC were only able to inhibit B-cell proliferation in the presence of $\mathrm{T}$ cells. It is known that inflammatory cytokines, in particular IFN- $\gamma$, are required to induce the antiproliferative effect of ASC on T cells [52]. IFN- $\gamma$ increases the expression of IDO and the inhibitory/coinhibitory molecule PD-L1 on ASC, which reduces the capacity of T cells to proliferate. Our results suggest that the requirement for activation of ASC also applies to the inhibition of B-cell proliferation. In the absence of activated T cells, IFN- $\gamma$ levels are low and ASC may not receive sufficient stimulus to induce an antiproliferative effects on B cells. These results suggest that ASC act in a feedback loop on B-cell proliferation. We propose that the activation of T cells leads to IFN- $\gamma$ and other inflammatory cytokine production, which in turn will activate ASC to dampen the proliferative response of both T and B cells (Fig. 6).

In contrast, ASC exerted direct effects on B cells by hampering the differentiation of $B$ cells into antibody secreting cells. The presence of $T$ cells was not required for the inhibition of B-cell differentiation into plasmablasts, as the effect was also observed when B cells were stimulated with a cocktail of antibodies (low dose anti-IgM, CD40 agonist) and cytokines (IL-2) to mimic antigen and T-cell help. Previously it was shown that MSC reduced antibody production in vivo in ovalbumin immunized mice [53]. In this model, CCL2 and CCL7 secreted by MSC were responsible for the reduction in immunoglobulin production. Similar results were found for lipopolysaccharide-activated B-cell differentiation and immunoglobulin production [22]. The fact that ASC inhibit immunoglobulin production independent of T cells suggests that ASC are capable of downregulating ongoing or chronic humoral responses when T-cell help is no longer required for building up the immune response.

While ASC on one hand reduced plasmablast formation, on the other hand they promoted development of 
$\mathrm{CD} 19^{+} \mathrm{CD} 24^{\text {high }} \mathrm{CD} 38^{\text {high }}$ IL-10 secreting B cells (Fig. 6). These cells resemble a transitional $\mathrm{B}$-cell phenotype and have regulatory properties by the secretion of IL-10 [50]. Moreover, they are associated with the control of autoimmune and inflammatory diseases [54]. The induction of regulatory B cells by ASC is interesting from a therapeutic point of view and recently it has been published that $\mathrm{CD}^{+} \mathrm{IL}-10$ secreting $\mathrm{B}$ cells are expanded in patients with refractory graft versus host disease after MSC treatment [26]. $\mathrm{CD}^{+}$IL-10-producing $B$ cells have been shown to be included in the $\mathrm{CD} 19^{+} \mathrm{CD} 24^{\text {high }} \mathrm{CD} 38^{\text {high }}$ subset [49] and exert a regulatory function on activated $T$ cells. Expansion of regulatory $B$ cells has been suggested to be an approach for the treatment of autoimmune disease [50]. In vivo induction of regulatory $B$ cells by administration of ASC is an alternative way to achieve this. Regulatory B cells may represent one of the drivers of the immunomodulatory effect seen after administration of ASC. Recent evidence suggests that ASC have a short lifetime after administration [55], and the induction of regulatory $B$ cells by ASC may be a mechanism that prolongs the immunomodulatory effects of ASC, even after they are no longer present in the recipient.

\section{CONCLUSIONS}

In summary, this work demonstrates that ASC have the capacity to modulate the $\mathrm{B}$-cell response to antigen by regulating B-cell differentiation. Our work indicates that ASC induce the formation of $B$ cells with regulatory properties, whereas they limit the formation of plasma cells with antibody-producing properties. ASC may represent a therapeutic option for the treatment of B cell-mediated disorders and humoral rejection of organ transplants or alternatively they can be a tool for in vitro generation of regulatory $B$ cells.

\section{ACKNOWLEDGMENTS}

The research leading to these results was partially funded by the European Union Seventh Framework Programme (FP7/2007-2013) under the Grant Agreement Number 279174 (REGENER-AR). Work in the laboratory of J.D.L. is supported by a program grant of the Dutch MS Research Foundation. R.H. is supported by a Fellowship from the Erasmus University Rotterdam (EUR).

\section{AUTHOR CONTRIBUtIONS}

M.F.: conception and design, collection of data, data analysis and interpretation, and manuscript writing; F.K.M.: conception and design, collection of data, and data analysis and interpretation; R.H.: conception and design, provision of study material or patients, and manuscript writing; T.S.: collection of data; L.B.: provision of study material or patients and final approval of manuscript; E.L. and O.D.R.: conception and design and final approval of manuscript; J.D.L.: provision of study material or patients and manuscript writing; J.M.G., W.W., and M.G.H.B.: final approval of manuscript; C.C.B.: administrative support, data analysis and interpretation, and final approval of manuscript; M.J.H.: conception and design, data analysis and interpretation, and manuscript writing.

\section{Disclosure of Potential CONflicts of INTEREST}

The authors indicate no potential conflicts of interest.

\section{REFERENCES}

1 Edwards JC, Szczepanski L, Szechinski J et al. Efficacy of B-cell-targeted therapy with rituximab in patients with rheumatoid arthritis. N Engl J Med 2004;350:25722581

2 Tyden G, Genberg H, Tollemar J et al. A randomized, doubleblind, placebo-controlled, study of single-dose rituximab as induction in renal transplantation. Transplantation 2009; 87:1325-1329.

3 Rocha PN, Butterly DW, Greenberg A et al. Beneficial effect of plasmapheresis and intravenous immunoglobulin on renal allograft survival of patients with acute humoral rejection. Transplantation 2003;75:1490-1495.

4 Pierce SK, Morris JF, Grusby MJ et al. Antigen-presenting function of $B$ lymphocytes. Immunol Rev 1988;106:149-180.

5 Swain SL, Dutton RW. Consequences of the direct interaction of helper T cells with $B$ cells presenting antigen. Immunol Rev 1987; 99:263-280.

6 Zeng $\mathrm{Q}, \mathrm{Ng} \mathrm{YH}$, Singh $\mathrm{T}$ et al. B cells mediate chronic allograft rejection independently of antibody production. J Clin Invest 2014;124:1052-1056.

7 Susal C, Opelz G. Kidney graft failure and presensitization against HLA class I and class II antigens. Transplantation 2002;73: 1269-1273.
8 Hodges AM, Lyster $\mathrm{H}$, McDermott A et al. Late antibody-mediated rejection after heart transplantation following the development of de novo donor-specific human leukocyte antigen antibody. Transplantation 2012;93:650-656.

9 Yanaba K, Bouaziz JD, Matsushita T et al. B-lymphocyte contributions to human autoimmune disease. Immunol Rev 2008;223: 284-299.

10 Reff ME, Carner K, Chambers KS et al. Depletion of $B$ cells in vivo by a chimeric mouse human monoclonal antibody to $C D 20$. Blood 1994;83:435-445.

11 Bernardo ME, Fibbe WE. Mesenchymal stromal cells: Sensors and switchers of inflammation. Cell Stem Cell 2013;13:392-402.

12 Duffy $M M$, Ritter $T$, Ceredig $R$ et al. Mesenchymal stem cell effects on T-cell effector pathways. Stem Cell Res Ther 2011; 2:34.

13 Meisel $R$, Zibert $A$, Laryea $M$ et al. Human bone marrow stromal cells inhibit allogeneic T-cell responses by indoleamine 2,3-dioxygenase-mediated tryptophan degradation. Blood 2004;103:4619-4621.

14 Caplan Al, Correa D. The MSC: An injury drugstore. Cell Stem Cell 2011;9:11-15.

15 Melief SM, Schrama E, Brugman MH et al. Multipotent stromal cells induce human regulatory $\mathrm{T}$ cells through a novel pathway involving skewing of monocytes toward anti-inflammatory macrophages. Stem Cells 2013;31:1980-1991.

16 Engela $\mathrm{AU}$, Hoogduijn MJ, Boer $\mathrm{K}$ et al. Human adipose-tissue derived mesenchymal stem cells induce functional de-novo regulatory T cells with methylated FOXP3 gene DNA. Clin Exp Immunol 2013;173:343-354.

17 Spaggiari GM, Capobianco A, Abdelrazik $\mathrm{H}$ et al. Mesenchymal stem cells inhibit natural killer-cell proliferation, cytotoxicity, and cytokine production: Role of indoleamine 2,3-dioxygenase and prostaglandin E2. Blood 2008;111:1327-1333.

18 Spaggiari GM, Abdelrazik $H$, Becchetti $F$ et al. MSCs inhibit monocyte-derived DC maturation and function by selectively interfering with the generation of immature DCs: Central role of MSC-derived prostaglandin E2. Blood 2009;113:6576-6583.

19 Francois M, Romieu-Mourez R, Li M et al. Human MSC suppression correlates with cytokine induction of indoleamine 2,3dioxygenase and bystander M2 macrophage differentiation. Mol Ther 2012;20:187195.

20 Eggenhofer E, Hoogduijn MJ. Mesenchymal stem cell-educated macrophages. Transplant Res 2012;1:12.

21 Franquesa M, Hoogduijn MJ, Bestard O et al. Immunomodulatory effect of mesen- 
chymal stem cells on B cells. Front Immunol 2012;3:212

22 Asari S, Itakura S, Ferreri K et al. Mesenchymal stem cells suppress B-cell terminal differentiation. Exp Hematol 2009;37:604-615. 23 Tabera S, Perez-Simon JA, Diez-Campelo $M$ et al. The effect of mesenchymal stem cells on the viability, proliferation and differentiation of B-lymphocytes. Haematologica 2008;93:1301-1309.

24 Comoli P, Ginevri F, Maccario R et al. Human mesenchymal stem cells inhibit antibody production induced in vitro by allostimulation. Nephrol Dial Transplant 2008;23: 1196-1202.

25 Guo Y, Chan KH, Lai WH et al. Human mesenchymal stem cells upregulate CD1dCD5(+) regulatory $B$ cells in experimental autoimmune encephalomyelitis. Neuroimmunomodulation 2013;20:294-303.

26 Peng $Y$, Chen $X$, Liu $Q$ et al. Mesenchymal stromal cells infusions improve refractory chronic graft versus host disease through an increase of $\mathrm{CD} 5+$ regulatory $\mathrm{B}$ cells producing interleukin 10. Leukemia 2014, 1-11. 27 da Silva Meirelles L, Chagastelles PC, Nardi NB. Mesenchymal stem cells reside in virtually all post-natal organs and tissues. J Cell Sci 2006;119:2204-2213.

$28 \mathrm{Kim} \mathrm{N}$, Im Kl, Lim JY et al. Mesenchymal stem cells for the treatment and prevention of graft-versus-host disease: Experiments and practice. Ann Hematol 2013;92:1295-1308.

29 Reinders ME, Rabelink TJ, de Fijter JW. The role of mesenchymal stromal cells in chronic transplant rejection after solid organ transplantation. Curr Opin Organ Transplant 2013;18:44-50

30 Maumus $M$, Guerit D, Toupet $K$ et al. Mesenchymal stem cell-based therapies in regenerative medicine: Applications in rheumatology. Stem Cell Res Ther 2011;2:14.

31 Hoogduijn MJ, Roemeling-van Rhijn $M$, Engela AU et al. Mesenchymal stem cells induce an inflammatory response after intravenous infusion. Stem Cells Dev 2013;22:2825-2835.

32 Hoogduijn MJ, Crop MJ, Peeters AM et al. Human heart, spleen, and perirenal fatderived mesenchymal stem cells have immunomodulatory capacities. Stem Cells Dev 2007;16:597-604.

33 Crop MJ, Baan CC, Korevaar SS et al. Donor-derived mesenchymal stem cells sup- press alloreactivity of kidney transplant patients. Transplantation 2009;87:896-906. 34 Wiken $M$, Bjorck $P$, Axelsson $B$ et al. Induction of CD43 expression during activation and terminal differentiation of human $B$ cells. Scand J Immunol 1988;28:457-464.

35 Mihara M, Kasutani K, Okazaki $M$ et al. Tocilizumab inhibits signal transduction mediated by both mIL-6R and sIL-6R, but not by the receptors of other members of IL-6 cytokine family. Int Immunopharmacol 2005;5: 1731-1740.

36 Huizinga R, van Rijs W, Bajramovic JJ et al. Sialylation of Campylobacter jejun endotoxin promotes dendritic cell-mediated $B$ cell responses through CD14-dependent production of IFN-beta and TNF-alpha. J Immunol 2013;191:5636-5645.

37 Hoogduijn MJ, Crop MJ, Peeters AM et al. Donor-derived mesenchymal stem cells remain present and functional in the trans planted human heart. Am J Transplant 2009; 9:222-230.

38 Dominici M, Le Blanc K, Mueller I et al Minimal criteria for defining multipotent mesenchymal stromal cells. The Internationa Society for Cellular Therapy position statement. Cytotherapy 2006;8:315-317.

39 Perez-Andres M, Grosserichter-Wagener $C$, Teodosio $C$ et al. The nature of circulating CD27+CD43+ B cells. J Exp Med 2011;208: 2565-2566.

40 Abdulahad WH, Meijer JM, Kroese FG et al. $B$ cell reconstitution and $T$ helper cel balance after rituximab treatment of active primary Sjogren's syndrome: A double-blind, placebo-controlled study. Arthritis Rheum 2011;63:1116-1123.

41 Hirano $T$, Ishihara $\mathrm{K}$, Hibi $M$. Roles of STAT3 in mediating the cell growth, differentiation and survival signals relayed through the IL-6 family of cytokine receptors. Oncogene 2000;19:2548-2556.

42 Kim J, Lee S, Kim YM et al. Human follicular dendritic cells promote germinal center B cell survival by providing prostaglandins. Mol Immunol 2013;55:418-423.

43 Schweighoffer E, Vanes L, Nys J et al. The BAFF receptor transduces survival signals by co-opting the $B$ cell receptor signaling pathway. Immunity 2013;38:475-488.

44 Belnoue E, Pihlgren M, McGaha TL et al. APRIL is critical for plasmablast survival in the bone marrow and poorly expressed by early-life bone marrow stromal cells. Blood 2008;111:2755-2764.

45 Nonoyama S, Hollenbaugh D, Aruffo A et al. B cell activation via CD40 is required for specific antibody production by antigenstimulated human B cells. J Exp Med 1993; 178:1097-1102.

46 Le Gallou S, Caron G, Delaloy C et al. IL2 requirement for human plasma cell generation: Coupling differentiation and proliferation by enhancing MAPK-ERK signaling. J Immunol 2012;189:161-173.

47 Krampera M. Mesenchymal stromal cell 'licensing': A multistep process. Leukemia 2011;25:1408-1414.

48 Hoogduijn MJ, Popp F, Verbeek R et al. The immunomodulatory properties of mesenchymal stem cells and their use for immunotherapy. Int Immunopharmacol 2010;10: 1496-1500.

49 Blair PA, Norena LY, Flores-Borja F et al. CD19(+)CD24(hi)CD38(hi) B cells exhibit regulatory capacity in healthy individuals but are functionally impaired in systemic Lupus Erythematosus patients. Immunity 2010;32: 129-140.

50 Kalampokis I, Yoshizaki A, Tedder TF. IL10 -producing regulatory B cells (B10 cells) in autoimmune disease. Arthritis Res Ther 2013;15(suppl 1):S1

51 Nagasawa T. Microenvironmental niches in the bone marrow required for B-cell development. Nat Rev Immunol 2006;6:107116.

52 English K, Barry FP, Field-Corbett CP et al. IFN-gamma and TNF-alpha differentially regulate immunomodulation by murine mesenchymal stem cells. Immunol Lett 2007;110: 91-100.

53 Rafei M, Hsieh J, Fortier S et al. Mesenchymal stromal cell-derived CCL2 suppresses plasma cell immunoglobulin production via STAT3 inactivation and PAX5 induction. Blood 2008;112:4991-4998.

54 Bouaziz JD, Yanaba K, Tedder TF. Regulatory B cells as inhibitors of immune responses and inflammation. Immunol Rev 2008;224:201-214.

55 Eggenhofer E, Benseler V, Kroemer A et al. Mesenchymal stem cells are short-lived and do not migrate beyond the lungs after intravenous infusion. Front Immunol 2012;3:297. 